\title{
O fazer a partir da Imagem: arte-criação em Sylvio da Cunha e Carlos Drummond de Andrade
}

\author{
Fernanda Zrzebiela*
}

\begin{abstract}
Resumo
Iniciamos este texto com o diagnóstico de uma inquietação: aquela do olhar que diante da fotografia se interroga a respeito do problema da aparição. Ao longo do trajeto percorrido pelo olhar "leitor" do poeta, que se mostra sensível ao eco das obras alheias, desdobram-se as especulações em torno do que seja uma arte verdadeiramente criadora, pelo amadurecimento da noção do fazer artístico que passa, necessariamente, pela inteligência do sensível. Diante de tais considerações, interessa-nos voltar a atenção para a emergência, na produção de Drummond após 1945, de um entendimento que concebe a criação artística a partir da imagem, em consonância com o diálogo possível que se pode estabelecer com as reflexões em torno da arte criadora, neste caso fotográfica, então desenvolvidas por Sylvio da Cunha em sua coluna intitulada "Os pássaros do retratista", mantida no suplemento Letras e Artes, do jornal A Manhã, a partir de 1947.
\end{abstract}

Palavras-chave: Poesia. Imagem. Carlos Drummond de Andrade. Sylvio da Cunha.

\section{The making as of the image: art-creation in Sylvio da Cunha and Carlos Drummond de Andrade}

\begin{abstract}
We start this text by diagnosing the restlessness opposite the problem of the apparition. Along the path described by the poet's watchful eye, which is sensitive to the contagion of others art works, we can observe the emergence of an artistic making notion as of the image. Our interest is to reflect on the creative dimension that this notion establishes in the poetry of Drummond, especially his poetry of memory, in line with the possible dialogue that can be established with the considerations about the creative photography, which were developed by Sylvio da Cunha in its column "Os pássaros do retratista", maintained in the newspaper A manhã, since 1947.
\end{abstract}

Keywords: Poetry. Image. Carlos Drummond de Andrade. Sylvio da Cunha.

Recebido: 30/01/2019

Aceito: 08/05/2019

\footnotetext{
* Universidade Federal de Santa Catarina (UFSC). Mestre em Literatura pela mesma instituição. Doutoranda em Literatura pela Universidade Federal de Santa Catarina (bolsista CNPq).
} 


\section{O enigma da aparição}

Datam do início do século XX os primeiros fotógrafos ambulantes do país. Estabelecendo-se nos principais espaços públicos de cidades como Belo Horizonte, a chegada de tais profissionais que ficaram conhecidos como "fotógrafos lambe-lambe" marca uma importante etapa no processo de expansão da indústria fotográfica no Brasil: saindo dos estúdios para ganhar as ruas, foi só por intermédio das máquinas-caixote que a fotografia se tornou acessível a uma grande parcela da população que não poderia pagar pelos sofisticados retratos dos estúdios fotográficos (ARROYO; SOUZA, 2011, p. 22).

Em Belo Horizonte, a chegada dos primeiros fotógrafos lambe-lambe remonta aos anos de 1920, período em que a cidade passou por um grande crescimento econômico, urbano e industrial. Como era de se esperar, o primeiro espaço público a recebê-los foi o Parque Municipal de Belo Horizonte: localizado numa região de convergência do fluxo da população oriunda de todas as regiões da cidade, o Parque foi, durante alguns anos, utilizado exclusivamente pela elite belo-horizontina, já que se localizava dentro da área planejada da capital. Com o tempo, entretanto, ele se tornou um espaço público de grande vitalidade, sendo frequentado por muitos turistas e por representantes dos mais variados segmentos sociais.

Em provável alusão a uma dessas cenas corriqueiras com que, porventura, se deparasse um transeunte observador da vida belo-horizontina no início do século, Drummond, então redator do jornal A Tribuna ${ }^{1}$ e residente da capital mineira, publica, em 1933, o texto intitulado "Os fotógrafos do parque".

Ainda que não se trate de uma reflexão aprofundada em torno da relação entre arte e fotografia - o que se daria anos mais tarde, em sua produção -, já se nota aí a latência de uma inquietação em torno do enigma da imagem, ou de seu aparecimento:

Às vezes me aproximo [...]. E vejo os postais emoldurados em cada canto da máquina, representando o sargento instrutor da Polícia Militar, a copeira de pensão em dias de folga, a mocinha de subúrbio que se esqueceu de fazer compras e foi respirar a poesia da vida, o antigo vereador do Norte de Minas em trânsito pela capital...Quem fixou esses tipos? Ninguém viu a hora em que eles se incorporaram à coleção de imagens do meu fotógrafo. Este não fez um gesto, a não ser o gesto grave de acender um cigarro e seguir, com os olhos, a linha feminina da fumaça. Tudo no jardim é silêncio e recolhimento, nem um tremor na tarde, e no entanto esses seres transeuntes insinuaram-se misteriosamente pela objetiva adentro e foram estampar-se na superfície branca de um cartão. Como? Com o auxílio de quem? Auto-reprodução inexplicável, que há de sempre constituir uma das perplexidades de minha vida (ANDRADE, 1967, p. 615).

Entre os diversos "tipos" que reconhece o poeta nos postais, determinados por suas ocupações cotidianas, assalta-lhe o mistério: quem os fixou ali? Embora a revelação não nos seja dada em fórmula pronta por esse sujeito que observa e indaga, fazem-se notar, por entre a "passividade" do fotógrafo e o protagonismo da própria imagem, as pistas de uma questão que ultrapassa o mero questionamento em torno da técnica fotográfica: o que está em jogo aqui parece ser muito menos o gesto da captura que o enigma da aparição.

Ninguém viu a hora que a imagem "se deixou" capturar. Como num acontecimento que se desse em surdina, as imagens insinuaram-se "misteriosamente pela objetiva adentro", incorporando-se à coleção. Talvez porque a imagem queria se captar - a "quem" se refere esse desejo? -, ela vive por conta própria.

1 Segundo a referência de Barbosa (1989, p. 57), o texto teria sido publicado originalmente no jornal Minas Gerais, também de Belo Horizonte, em 1933. Quando sai no mesmo ano, em A Tribuna, o texto traz a assinatura de Belmiro Borba, pseudônimo que teria sido criado, segundo Fernando Py, por Cyro dos Anjos. O escritor esclareceu que, além dele, somente Drummond o utilizara, numa ocasião em que Cyro teve de se ausentar de Belo Horizonte. "Belmiro Borba" foi utilizado, mais tarde, para designar o protagonista do romance $\mathbf{O}$ amanuense Belmiro (1936). (Cf. PY, 2002, p. 215). 
A essa inversão de posições corresponde a integração dos fotógrafos à paisagem, chegando mesmo o cronista a defini-los: "seres de natureza quase vegetal". É sintomático pensar, nesse sentido, que o mesmo texto é republicado em 1942 com o título "Os fotógrafos vegetais", 2 justamente em um contexto no qual a atenção do poeta parece se voltar mais detidamente a pensar questões entre forma, imagem e poesia.

Se tivéssemos que situar uma espécie de marco ou ponto norteador na obra de Drummond a partir do qual se verificaria um acercamento mais estreito das especulações do poeta em torno de tais questões, partiríamos do período que abarca sua produção depois de A rosa do povo.

Isso não significa, contudo, excluir do recorte proposto a obra de 1945: recordemos que é desse período a publicação de poemas como "Procura da poesia", "Consideração do poema" e "Vida menor", por exemplo, nos quais já se mostra flagrante uma incipiente noção do fazer que desautoriza uma espécie de "autonomia soberana" do artista criador, porque pressupõe, de um lado, a existência autônoma das palavras (e das coisas); e, de outro, o trabalho intelectual (mas não somente) do artista que traduz ou "torna visível" a aparição dessas mesmas coisas também porque se coloca, em certo sentido, "receptivo" a elas.

Se poesia é aquilo que "fala" (a imagem, aquilo que "aparece"), o poema não seria, então, mais do que o meio "tradutor", por assim dizer, dessa aparição. De modo que a pergunta, outrora pela autoria (quem), converte-se, aos poucos, em interesse pelo modo de fazer.

Fato é que a "guinada classicizante", operada pelas quatro obras que ficaram conhecidas, pela definição de Merquior (2012, p. 176), como o "quarteto metafísico" da poesia drummondiana, marca um período de resgate "consciente" mais expressivo da tradição, o que aponta mais para um modernismo classicizado do que para um classicismo moderno (MERQUIOR, 2012, p. 259), alinhando-se a uma compreensão muito próxima daquilo que, nos moldes da conhecida "poesia tardia", de Hölderlin, poderia se pensar em termos de uma combinação entre intelecto e sentido vivo.

É desse período, por exemplo, a publicação de “A tela contemplada", ${ }^{4}$ poema posteriormente incluído em Claro enigma, no qual o poeta parece colocar em xeque justamente a estéril soberania do artista que, ao contrário do uso consciente da forma e do sentido, promovido pela inteligência do sensível, reduz o fazer artístico à mera captura da paisagem, emoldurando-a em arranjos preestabelecidos de "quadros" sem vida.

Com efeito, em Claro enigma, o poeta se refere com frequência à arquitetura e à construção, em composições que são testemunhos de um desejo aparentemente frustrado de construir e abstrair (GLEDSON, 2002, p. 163), e às quais se pode ainda acrescentar o próprio epíteto provocativo de "fazendeiro do ar", cuja etimologia diz respeito a coisas que devem ser feitas ("facenda", do latim vulgar) e, portanto, construídas, arquitetadas, ao mesmo tempo em que o poeta, pela tarefa que lhe é própria, dispõe para tal intento de materiais diáfanos, feitos de sonho, que se desmancham no ar.

\section{Arte em diálogo e o problema da criação}

O momento, no entanto, não evidencia somente uma preocupação mais expressiva em relação aos problemas da forma e do sentido na criação do poema: ele aponta igualmente um período em

2 O texto sai em 29 de julho daquele ano no suplemento Autores e Livros, do jornal A Manhã, e é depois incluído, com o mesmo título, em Confissões de Minas.

3 "Que é poesia, o belo? / Não é poesia, / e o que não é poesia não tem fala". Versos do poema "Conclusão". In: Fazendeiro do Ar. (ANDRADE, 1967, p. 279).

4 Publicado em 10 de setembro de 1950, no Correio da Manhã (RJ) (ANDRADE, 1950). 
que Drummond se volta a pensar mais detidamente os problemas da forma e do sentido também na obra de outros artistas, inclusive na obra daqueles que lhe foram contemporâneos, demonstrando o interesse de um poeta que se mostrou ter sido desde sempre afeito ao contágio das outras artes, não só da fotografia, como também da música e das artes visuais. ${ }^{5}$

Isso porque, como já notou Silviano Santiago no posfácio que escreve a Farewell (ANDRADE, 1996, p. 105-129), enquanto poeta, Drummond foi, antes de tudo, um extraordinário leitor. Não apenas leitor de livros, mas ainda e sempre "leitor": das artes plásticas, dos filmes, das fotografias, do mundo. É que, como define o próprio poeta nos "Apontamentos" de Passeios na ilha, ao escritor recai "não somente certa maneira especial de ver as coisas, senão também a impossibilidade de vê-las de outra maneira qualquer." (ANDRADE, 1967, p. 675).

Certamente o olhar desempenha aqui uma função múltipla: é tanto a "ferramenta" que impulsiona a criação porque retira o véu que encobre as coisas e se detém na essencialidade de sua nudez quanto "instrumento" que possibilita a leitura das coisas refiguradas. É que, assim como a fotografia "dilata" a imagem, a função quase tátil do olhar sensível dilata o instante, ao concentrar o fluxo do tempo em um momento decisivo. O resultado dessa brusca suspensão que paralisa por um infinito instante tudo aquilo que o olho então vê e celebra ${ }^{6}$ não pode ser outro senão aquele da cristalização, operada na temporalidade nova em suspensão, que converte as formas em imagem.

Passeios na ilha, a propósito, reúne textos em que Drummond comenta a obra de Manuel Bandeira, João Alphonsus, Raul Bopp, Emílio Moura e Henriqueta Lisboa, por exemplo, mas sobretudo neste, que é um momento de reavaliação crítica do Modernismo, as poesias de Américo Facó e Joaquim Cardozo. Ambos são, em certo sentido, considerados por Drummond poetas "ausentes", que não tomaram partido nas batalhas do Modernismo, mas enfaticamente não eram simplesmente reacionários, no sentido de um retorno ao convencionalismo dos anos anteriores a 1920 (GLEDSON, 2002, p. 152).

É também de Passeios na ilha o texto que Drummond escreve a Sylvio da Cunha, intitulado "O poeta e a fotografia", publicado originalmente em 20 de julho de 1947, no Correio da Manhã (RJ), ${ }^{7}$ e só depois recolhido, com ligeiras modificações, no livro de 1952.

Foi Cunha, aliás, quem chamou a atenção para a existência, o mais das vezes despercebida pelo olhar fatigado do mundo visível, de "um lirismo despistador" que dorme "em certos retratos onde se cravam as máscaras incertas das coisas", em humildes objetos que a nossa mão ou o nosso pé despreza": "Por que só a fotografia os descobre aos nossos olhos tão cegos para os nove décimos do mundo? Recomeça o enigma." (CUNHA, 1947a, p. 10).

\footnotetext{
5 Na coluna oportunamente intitulada "Imagens", a qual o poeta manteve no Correio da Manhã entre 1954 e 1969 , é possível encontrar, entre outros assuntos, textos que versam sobre as artes plásticas, como é o caso de "Arte-imagens, um tema", de 6 de setembro de 1967, no qual, a pedido de um leitor, Drummond descreve um rápido panorama a respeito da temática da medicina, tratada por diversos pintores. Além deste, outros dedicados a pintores como Segall, Portinari, Guignard, Goeldi e Antônio Bandeira, por exemplo. Não custa lembrar que, antes mesmo da referida coluna, Drummond já trazia a público, no mesmo jornal, diversas "Antologias", dentre as quais se destaca aqui aquela que reúne "Os poetas e os nossos pintores", ilustrada com quadros de Segall e Portinari no Correio da Manhã, Rio de Janeiro, em 25 de junho de 1950 (Cf. ANDRADE, 1950).

6 Refiro-me à oportuna diferenciação que faz Valéry, em sua belíssima "Composição de um porto", quando invoca uma "linguagem repleta de termos barrocos, exuberantes e de todas as épocas, como o latim de Apuleio" para "celebrar (não descrever, que é um trabalho infeliz) tudo aquilo que satura a visão, a audição e o olfato, que excita o espírito, diverte o ser, nas beiradas, nos píers, sobre a água pesada de um porto marítimo." (VALÉRY, 2016, p. 160-161).

7 Saiu também, com modificações, com o título "O poeta fora do mercado", em A Tribuna, (Santos em 22 de junho de 1947 apud ANTELO, 2014, p. 77).
} 
Artista pouco conhecido do público, ${ }^{8}$ Sylvio da Cunha (1907-1995) estreava em abril de 1947, no suplemento Letras e Artes do jornal A Manhã, a coluna intitulada “Os pássaros do retratista". Como explica o próprio Sylvio, que se sentia tocado pelo "nosso grande poeta e prosador, mesmo na prosa mais banal", o título se inspirava em uma crônica na qual Drummond se refere à "câmara escura onde adormecem os pássaros do retratista".

Mais do que uma teoria da fotografia, no entanto, Cunha ensaiaria em sua coluna uma verdadeira antropologia do sensível sob o ponto de vista da imagem, conforme nota Raúl Antelo (2014, p. 52), tal como os pioneiros Alfred Stieglitz ou Marius de Zayas, nas páginas de Camera Work. À diferença, contudo, dos precursores, o referencial de Sylvio da Cunha era basicamente poético, como se pode pressentir logo no primeiro texto da coluna quando o artista procura ressaltar um dos objetivos a que se propõe: "procuraremos também [na fotografia] o seu lirismo e a sua poesia".

Seria de se esperar que tal advertência funcionasse como um preparo de recepção para os textos que o fotógrafo publicaria dali em diante. Mas quem poderia estar, de fato, preparado para se defrontar com o arrebatador exercício do olhar sensível que nos presenteia, em setembro daquele ano, não apenas o fotógrafo, mas sobretudo o poeta Sylvio da Cunha?

[...] Já vos aconteceu, estou certo, ver a sombra da roupa desenhar um perfil humano ou de animal no chão; uma bolha no sabonete e um pouco de espuma formam um olho e um nariz, tudo faz uma expressão de espanto; alguma folhagem, ao cair da tarde de sol, projetava ontem no muro um coelhinho, a que a brisa dava vida; vi as dobras de um lenço formarem uma cara de gente e um papel de embrulho amarrotado num canto compor uma face austera, episcopal. São geralmente figuras nirvânicas, expressando uma grande concentração de indiferença e alheamento. Caras de mortos. Espesso de arabescos como uma floresta, este mármore. É sem trabalho que o meu olhar fixo perplexo com o desaparecimento do copo d'água vê nas sinuosas veias surgirem dois cavalheiros da Inquisição, ou da Ku-KluxKlan. Em seguida vem um cachorro sem mandíbula inferior junto de um velho com a boca desmesuradamente aberta. É o olhar que desenha estes monstros ou eles existem, no seu estado de pedra? Onde está a realidade? (CUNHA, 1947g, p. 8). ${ }^{9}$

Está visto que nessa passagem, aparentemente despretensiosa, já se revela muito do que irá propor Cunha em torno do que seja uma arte - neste caso, fotográfica - verdadeiramente criadora. É que em

8 Em 30 de março de 1947, no anúncio da nova seção do suplemento Letras e Artes, encontra-se uma breve apresentação do novo colaborador: "Letras e Artes apresentará em seu próximo número uma nova e interessante secção sobre assuntos fotográficos, sob a responsabilidade de Sylvio da Cunha - essa estranha figura de nossa poesia que, apesar de fugir à publicidade, tem garantido o seu lugar no plano do nosso desenvolvimento artístico. É autor de dois livros publicados fora do comércio, Constança e Memória da Passagem do Anjo. Em 1943, Sylvio da Cunha se tornou repentinamente um autêntico aficionado da fotografia. Seus trabalhos foram dos mais relevantes, nesse período. Sempre preocupado em estudar a parte da física que trata dos fenômenos luminosos, adquiriu um telescópio e mais tarde um microscópio, tendo com este feito fotografias de algas e preparações anatômicas de zoologia e botânica. Em 1944, começou a acreditar na possibilidade da fotografia como arte, fazendo as primeiras composições e procurando conhecer a obra de fotógrafos contemporâneos e antigos. Fez em seguida uma série de foto-micrografias para o Instituto Nacional de Cinema Educativo. Expôs recentemente em Quitandinha, e aparecerá brevemente numa exibição no Photography Center do Museu de Arte Moderna de Nova York”. Sylvio estrearia sua coluna em 6 de abril daquele ano, mas como acrescenta Raúl Antelo (2014, p. 47), a essa altura ele já era conhecido, tendo exibido suas próprias fotos no Instituto dos Arquitetos do Brasil, na Praça Floriano, no prédio da Livraria Victor, em 4 de junho de 1947.

9 Prossegue Sylvio na deliciosa celebração da imagem: "O olhar vai girando e vê o cavalo com cara de passarinho, cuja perna da frente é um martelo e cujo corpo é um estandarte esfarrapado. O rato está aí, com cabeça de barata. Um homúnculo se bifurca em pássaro e a sua perna o precede, agressiva, em atitude de marcha prussiana. Um boi tem bigodes e um olho no meio da testa. Um cachorrinho devora uma flor com a pata dianteira. Um ancião de cavanhaque, cuja cabeleira forma a efígie de Lamartine. De costas, uns ombros, uma cartolinha, que poderiam ser de Carlitos. Três figuras sendo duas encapotadas e um homem com corpo de peixe. Cara de homem vociferando e orelhas de gato. Mulher com chapéu de astrólogo cujo corpo forma uma focinho de cão. Figuras de Guernica, de Breughel e Bosch, de Salvador Dalí. Caras repuxadas ora nos olhos, ora na boca, nos lábios, com um só olho, ou sem boca ou sem nariz, caras cortadas ou meio dissolvidas. Mistérios do mármore. Boca enorme engolindo uma árvore. Aos pés da árvore vejo enfim o copo d'água. Caprichos do olhar." (CUNHA, 1947g, p. 8). 
se tratando de fotografia, entende o artista que "na imensa maioria das vezes" não estamos diante de uma obra de arte, mas "simplesmente da conservação de uma lembrança ou da determinação de um documento"; poucas, ou mesmo raríssimas são aquelas que produzem o sutil e profundo "sentimento estético" (CUNHA, 1947e, p. 6).

Percebe-se, então, o esforço por tentar definir uma estética para essa linguagem, chegando mesmo a apresentar as bases do que chamará de "fotografia pura": ao lado da intensificação do sentimento de percepção, pelo enriquecimento em nitidez e do detalhe, além do aumento dos valores espaciais pelo claro-escuro e perspectiva, tais composições se diferenciariam das demais por carregarem em si o aparecimento de uma quarta dimensão - o tempo.

Quando se escolhe um motivo e se estuda a sua composição, quando se destaca um detalhe ou se busca um ângulo de vista, um gesto, um efeito de luz, e principalmente, quando de uma dificuldade se tira um novo efeito, assim como "poeta que tira da rima uma nova imagem", aí se está fazendo realmente, segundo Cunha, uma obra de arte.

À tal fotografia, verdadeiramente criadora, caberia a força da síntese poética, "que traz do caos (no sentido mais metafísico) as relações ainda não pressentidas e as faz do domínio geral do conhecimento até que passem à categoria analítica como sinais de espécie e ordem". É ainda tal força, continua Cunha, "que se renova periodicamente, quando as associações se esgotam e a expressão se torna impotente para cumprir o seu fim mais alto, que é a criação de aspectos novos do espírito" (CUNHA apud ANTELO, 2014, p. 49). ${ }^{10}$

Naturalmente, a criação assim concebida exclui "imitação, repetição e 'academia'". ${ }^{11}$ Caberia ao verdadeiro artista recriar a imagem, ao contrário de apenas descrevê-la. ${ }^{12}$ Pois, como defende o fotógrafo, aquele que produz a natureza em seus íntimos detalhes, "ponto por ponto, com uma fidelidade assombrosa", revela com isso ausência total de imaginação e, portanto, incapacidade de criar (CUNHA, 1947b, p. 6).

É o próprio Goethe, citado na "Antologia" dos mestres do passado aos quais se deve sempre recorrer o artista em busca de "novas forças de renovação", quem nos esclarece a respeito da potência criadora da imaginação, motivada mesmo pela mais fortuita das situações:

Não me diga que à realidade falta interesse poético. É com ela precisamente que o poeta se manifesta, se ele tem bastante espírito para discernir num tema vulgar um lado interessante. A realidade fornecerá os motivos, os pontos a trazer a luz, o fundo propriamente dito; o labor do poeta consiste em formar com esses elementos um todo gracioso e animado. Há poucos homens que possuem a imaginação própria para conceber as realidades. Ao contrário, todos gostam de transportar seu pensamento em regimes e situações estranhas que em seguida agem sobre a própria imaginação e a distorcem. Há ainda os que se agarram à realidade e que são nesta conformidade, de uma exigência meticulosa, porque são completamente destituídos de poesia. [...] Nossos artista ingênuos, que se voltam para a imitação da natureza, com sua debilidade pessoal e sua impotência artística, imaginam que fazem muito. Mas é abaixo da natureza que eles estão. Ora, quem quer que seja que procure produzir uma grande obra, deve ter elevado sua educação a um tal nível, que alcance, como

10 Trata-se de um trecho de carta enviada por Sylvio a Drummond, em 4 de fevereiro de 1945, mantida sob guarda do Museu de Literatura Brasileira da Fundação Casa de Rui Barbosa.

11 Isso não significa, evidentemente, ignorar os mestres do passado. Como explica Sylvio, "não se chega a dominar os elementos do mundo exterior, ao desembaraço das próprias faculdades, sem ter passado pelas pegadas e pelos traços de nossos maiores e sem ter aprendido tudo o que eles souberam. E é só fazendo do ponto onde eles ficaram o nosso ponto de partida que alcançaremos a ser originais. Ignorar o que já se fez e assim mesmo pretender criar coisas novas é uma pobre estultice" (CUNHA, 1947c, p. 6).

12 Elucida, a esse respeito, o seguinte fragmento, não assinado, com o título "Rimbaud explica o método de sua poética", que se encontra ao final de "Os pássaros do retratista": "Na 'Alquimia do Verbo' Rimbaud dá-nos a ideia do seu método: a busca sistemática da alucinação, a procura de uma linguagem que permita traduzir os estados mais confusos da alma graças a uma evocação sensual simultânea de um complexo de tendências obscuras. Recriar a emoção no leitor, em lugar de descrevê-la. [...]". 
os gregos, a atrair na alta esfera do seu gênio, a débil realidade que a natureza lhe oferece, e de dar uma existência real às coisas que, nos fenômenos da natureza, permanecem no estado de intenção [...] (CUNHA, 1947d, p. 6).

É a natureza, para o verdadeiro artista, um inesgotável repertório de motivos e nela importa menos os motivos do que propriamente as relações que dela se pode depreender. Sendo assim, "todos os espetáculos, todas as emoções, todos os sonhos, resumem-se", para ele, "em combinações de manchas, em relações de tons e de tintas, em linhas" (CUNHA, 1947d, p. 6).

Drummond, que já prefaciara o livro do amigo, ${ }^{13}$ comentará o trabalho do fotógrafo, no texto já citado, com base num entendimento da criação artística muito próximo daquele que elabora Sylvio ao longo de sua coluna no Letras e Artes.

Partindo da "inevitável poesia específica que se desprende de cada procedimento técnico, exercido com amor e rigor", Drummond destaca um ponto fundamental no trabalho do fotógrafo, e que tomamos como igualmente assimilável à poética drummondiana do período: "o poderoso sentido plástico da imagem" - “(não privativo da pintura)", ressalta o poeta - “[...] imagem que ele não apenas capta, senão também seleciona e como que torna a criar, aproximando ou fundindo elementos que se ignoravam [...]. Suas fotografias dão testemunho de um artista geral, sutilmente dotado, combinando imaginação e artesanato [...]”. (ANDRADE, 1967, p. 718).

Cumpre notar o quão próximos estamos aqui de uma verdadeira sintaxe da montagem: ao propor um entendimento da tarefa de "ordenação" do caos, que cabe a todo artista, na combinação entre "imaginação e artesanato", Drummond nos convoca a (re) pensar o processo de criação pelo qual o saber, resultante de um trabalho inscrito no campo turbilhonante da imagem, adquire uma nova "aparência", isto é, o saber que nasce da possibilidade de vertigem.

Se podemos pensar, com Jacques Rancière (2012, p. 86-87), que com a ascensão do regime estético das artes e a consequente ruptura dos "fios da representação" se dá o triunfo da imagem sobre palavraou seja, "as palavras não mais prescrevem o que devem ser as imagens, uma vez que as formas visíveis são agora apenas signos da ideia invisível" -, somos então levados a considerar que ao, contrário da "paisagem" capturada e congelada no "quadro" hermético, proposto pelo regime representativo, o que a insubordinação às formas fechadas da composição impõe é a fissura do "quadro" pela superação da fixidez que toda imagem promove.

Não mais expressão codificada de um pensamento ou de um sentimento, um duplo ou uma tradução, a imagem emerge, então, como a eloquente palavra muda das coisas, como linguagem visível a ser decifrada, passando a indicar justamente a possibilidade de "aparecimento" dessas mesmas coisas. De modo que a expressividade da obra, nesse sentido, só revela à medida que o olhar sensível se põe, por um desvio, a experimentar a "soberana imposição" do não-saber por parte de toda imagem, ao escavar a dupla dimensão da superfície que se conjuga entre evidência (aparecimento, epiphasis) e inevidência (desaparecimento, aphanisis) (DIDI-HUBERMAN, 2012, p. 36), na contramão das concepções universais de uma história da arte humanista, afeita a subsumir na Ideia, no Esquema, no Símbolo, com suas exigências de visibilidade ou de clareza (FONTES FILHO, 2012, p.15).

Pela imagem se dá a instauração, portanto, daquilo que, numa problemática do movimento, plástico, virtual, permanece capaz de chocar, de deslumbrar e de transformar o pensamento, tal como um fragmento de vida que se colasse à superfície, possibilitando a constituição, sempre renovada, de uma nova visibilidade, à medida que um novo ângulo, um novo detalhe, seja percebido pelo olhar

13 Trata-se do livro Memórias da passagem do Anjo, de 1944. Exemplar mantido sob guarda do Museu de Literatura da Fundação Casa de Rui Barbosa, Rio de Janeiro. 
sensível - em outras palavras, um olhar cuja prática depende, necessariamente, de um pensamento, já que o "quadro" resultante dessa operação é justamente aquele que se oferece a um olhar formado para ver de outra forma.

Talvez resida aía eficácia fundamental do trabalho com as imagens: instaurar relações transgressivas, alterantes, transformadoras. Como bem coloca Didi-Huberman $(2015$, p. 23) a respeito do trabalho de Bataille em Documents, e que em certa medida pode ser pensado como contíguo ao trabalho de imagem a que se propõe também o poeta, trata-se aqui menos de um sentido a ser dado do que um sentido a ser retirado, com a finalidade de criar um vasto conjunto aberto de relações. Sendo assim, o trabalho que se guia pelo dilaceramento da fixidez do "quadro" só pode se dar por uma noção que privilegie as relações em detrimento dos termos, ou seja, que se guie fundamentalmente pelo conhecimento das relações entre os diversos elementos.

Não se trata aqui, portanto, de aproximar e fundir, pelos tertia comparativos, elementos que aparentemente se ignoravam, mas de identificar e pressentir as relações imediatas de afinidade entre os seres, sustentadas pelo sentimento (BENJAMIN apud MOLDER, 2009, p. 32), capazes de enxergar o todo no fragmento. Operação, aliás, capaz de perturbar o próprio conhecimento, na medida em que o produz sob uma nova aparência, isto é, aquela do conhecimento inaudito da vertigem.

\section{Imagem, vida última dos seres}

Em 1949, no texto "Retratos do artista quando menino", publicado no Jornal de Letras (RJ), ao comentar uma série de retratos de infância de diferentes artistas, valendo-se das observações de Valéry a respeito, Drummond retomará as especulações em torno desse misterioso sentido plástico da imagem, sentido esse capaz de captar e fornecer um "número prodigioso de estrelas, radiações e energias cósmicas", os quais só se tornaram conhecidos graças à fotografia. São "energias, radiações e estrelas", afirma o poeta, "que, por assim dizer, ficamos devendo à placa sensível do fotógrafo":

Mas essa placa não nos desvenda somente os mundos longínquos e as vibrações imponderáveis da matéria. Os nossos próprios mundos individuais, o mundo interior que se defende por trás das aparências catalogadas do mundo de todos os dias - o fotógrafo consegue, muitas vezes, captá-lo em sua pureza sigilar, quando nem o psicólogo nem o pedagogo nem o ficcionista dele retiram mais que um esboço confuso (ANDRADE, 1949, p. $8-9) .{ }^{14}$

Os retratos dos artistas quando crianças, dispersos pela página do jornal, conclui o poeta, atestam essa faculdade que tem o retrato de nos mostrar algo mais que a forma de um nariz ou a proeminência de um queixo: "o sentido divino da expressão, do rosto humano, a trair-nos o seu segredo, logo devassado por esse detetive, que é o fotógrafo", num entendimento muito próximo daquele expresso por Sylvio da Cunha em sua coluna, quando este afirma comportar o retrato o incontestável triunfo da fotografia. Caberia, pois, ao fotógrafo escolher "a atitude, a máscara mais cheia de consequências" pela qual se revela o instante dilatado que, na mobilidade de uma face humana, alcança a individualidade do retratado e a compõe em seu aspecto mais típico (CUNHA, 1947h, p. 8).

$\mathrm{O}$ que exerce poder de fascínio interrogante daquele que se dirige a olhar a fotografia não se resume, no entanto, ao virtual que fissura o "quadro" e que o torna, por assim dizer, vazado, capaz de "desvendar", tirar, de fato, a venda que recobre muito mais que a expressão do rosto, "o mundo

14 O texto é assinado com o pseudônimo de "M.P.", segundo Raúl Antelo (2014, p.49), único texto em que Drummond utiliza essa acrografia. Uma adaptação do mesmo texto aparece em 10 de junho, no Correio da Manhã, sob o título: "Imagens de criação, os marcados" (ANDRADE, 1958b). 
interior que se defende por trás das aparências catalogadas do mundo de todos os dias": existe ainda o mistério que há por trás do simples fato de que, ao ter sido "fixada", a forma adquirir sobre a nossa sensibilidade um poder que ela mesma não tinha - "Surge então o mistério, a magia: um objeto cuja vista deixa-nos completamente indiferentes, transposto para uma superfície plana e limitada, produznos uma emoção estética" (CUNHA, 1947f, p. 6). ${ }^{15}$

Talvez porque, como expressa o poeta nos belíssimos versos de "A saudação da infância", poema publicado no Jornal do Brasil ${ }^{16}$ por ocasião da exposição do fotógrafo Alécio de Andrade, "a imagem, vida última dos seres" (ANDRADE, 2016, p. 50), ${ }^{17}$ seja também um ser vivo, como os demais seres:

Olha, descobre este segredo: uma coisa são duas - ela mesma e sua imagem

Repara mais ainda. Uma coisa são inúmeras coisas.

Sua imagem contém infinidade de imagens em estado de sonho, germinando no espaço e [na luz.

E as criaturas são também assim, múltiplas de si mesmas.

A variedade de imagens revela o mundo que nasce a cada instante em que o contemplas: [formas, ritmos, ângulos, expressões, impressões, fragmentos, síntese

A imagem é um ser vivo, como os demais seres. E quer penetrar em teu espírito, habitá-lo [como hóspede afetuoso.

Se a recolheres com toda a pureza da vista e completa simpatia da mente, ela te enriquecerá. Estas imagens vão mais longe do que os meios intersiderais de comunicação. Insinuam-se [na profunda região da vida.

Conversam daquele assunto que carregas contigo como baú nostálgico.

O baú abre-se, e tua infância te saúda, com inocência de fonte.

Não pode haver melhor uso da fotografia do que este de alimentar-nos da porção perdida [de nossa alma.

Uma arte vinculada com a mais fugitiva e perene das realidades poéticas, eis o dom sublime [de Alécio de Andrade.

Os versos, que na ocasião da publicação aparecem dispostos ao lado da fotografia de uma garotinha em seu velocípede, parecem, de fato, incorporar um tom de conselho ou confidência que é assegurado pelo convívio de um "ser" que germina "no espaço e na luz"; que é vário e revelador em sua multiplicidade; que não somente "vive" como os demais seres como também "quer" habitar o espírito; e que, por fim, insinua-se "na profunda região da vida", como um fragmento que se infiltra no "quadro" e o multiplica infinitamente. É, pois, a própria imagem "quem" abre o baú da infância, de segredos longínquos, porque ela é, afinal, essa profusa infiltração de luz que as rachaduras do passado ilumina: energias, radiações, estrelas, sonhos, meios intersiderais, espaço e luz, ser vivo, imagem tanto em "Retratos do artista quando menino" quanto em "A saudação da infância", não poderia ter sido mais feliz o poeta em sua tarefa de pintar, pela palavra, a centelha de vida que a imagem carrega.

Em suma, o que Drummond parece nos assegurar é a ideia de que, sendo uma centelha de vida que pulsa, toda imagem descreve o movimento de uma fulguração própria que não se inscreve no

15 “[...] Seria portanto explicável por que nos comovem tanto essas fotografias amarelecidas, em que os personagens parecem estar sob um véu de tempo, numa melancólica névoa, que a poucos centímetros dos nossos olhos os coloca tão desoladoramente distantes. Como na pintura, o sentido plástico da fotografia é um refinamento tardio" (CUNHA, 1947f, p. 6).

16 Em 27 de setembro de 1964. O poema é precedido da seguinte nota: "Esta e outras fotos assim, refletindo a ternura da infância, poderão ser vistas, a partir de amanhã, numa exposição de Alécio de Andrade, cujos detalhes estão na última página". Adiante: "O Itinerário da Infância de Alécio de Andrade será aberto ao público amanhã às 21 horas, na Petite Galerie. Trata-se de uma exposição de fotografias, preparada com classe artística de nível internacional, por Alécio de Andrade, com patrocínio da Divisão Cultural do Itamarati e do Banco Soto Maior. [...] A apresentação da mostra foi entregue ao escultor Amílcar de Castro, para ficar tudo de primeira classe. O Itamarati levará depois a exposição para a Europa".

17 Trata-se do último verso do poema "Imagem, Terra, Memória", do livro Farewell. O poema é inspirado em uma coleção de velhas fotografias de Brás Martins da Costa. 
âmbito de uma identidade substancial, a qual se pudesse apreender de forma absoluta por aquele que se disponha a alcançá-la. Pelo contrário, a exemplo das admiráveis "borboletas" de Warburg, o que as imagens descrevem nada mais é que a dança fascinante e misteriosa, não de termos - "no duplo sentido mesmo que a palavra incorpora: tanto elemento isolável quanto última etapa de um processo" (DIDI-HUBERMAN, 2015, p. 199), mas de relações em movimento, sempre fugidias e alteradas, pois as "fotografias da memória", como chamará Sylvio da Cunha,

móveis ou elásticas, caprichosas ou fiéis, têm o seu lugar certo no quadrante misterioso e feito de camadas sucessivas do espírito. Não haveria máquina, por mais inteligente que fosse, capaz de colhê-las; elas são feitas de poesia e de intuição impalpáveis, de segredo apenas pressentido, de música incerta e subterrânea (CUNHA, 1948, p. 11).

"São feitas de poesia e intuição": tudo aquilo que possibilita, ao olhar destreinado de ver, sentir - porque não haveria aqui melhor termo para definir este gesto - as misteriosas cintilações que das imagens emanam e que se fazem, por vezes, notar.

\section{Referências}

ANDRADE, Carlos Drummond de. A saudação da infância. Jornal do Brasil. Rio de Janeiro, 27 set.1964b. Cad. B, p.1.

ANDRADE, Carlos Drummond de. A tela contemplada. Correio da Manhã. Rio de Janeiro, 10 set. 1950. Cad. 5, p. 1.

ANDRADE, Carlos Drummond de. Farewell. Posfácio Vagner Camilo. São Paulo: Companhia das Letras, 2016.

ANDRADE, Carlos Drummond de. Farewell. Rio de Janeiro: Record, 1996.

ANDRADE, Carlos Drummond de. Imagens de criação, os marcados. Correio da Manhã, 1958b.

ANDRADE, Carlos Drummond de. Imagens do espírito. Correio da Manhã. Rio de Janeiro, 23 mar.1958a. Cad. 1, p. 6.

ANDRADE, Carlos Drummond de. Imagens alheias - Lição de Joubert. Correio da Manhã. Rio de Janeiro, 17 ago.1962. Cad. 1, p. 6.

ANDRADE, Carlos Drummond de. Imagens alheias - Lição de Joubert. Correio da Manhã. Rio de Janeiro, 5 fev.1964a. Cad. 1, p. 6.

ANDRADE, Carlos Drummond de. Obra completa. 2. ed. Rio de Janeiro: José Aguilar Editora, 1967.

ANDRADE, Carlos Drummond de. O poeta e a fotografia. Correio da Manhã. Rio de Janeiro, 20 jul. 1947, 2. Seção. p. 1.

ANDRADE, Carlos Drummond de. Retratos do artista quando menino. Jornal de Letras. Rio de Janeiro, nov. 1949.

ANTELO, Raúl. Uma (outra) pequena história da fotografia: Sylvio da Cunha. História: Questões \& Debates. Curitiba, n. 61, p. 45-77, jul./dez. 2014.

ARROYO, Michele Abreu; SOUZA, Françoise Jean de Oliveira (Org.). Fotógrafo Lambe-lambe: retratos do ofício em Belo Horizonte. Belo Horizonte: Fundação Municipal de Cultura, Diretoria de Patrimônio Cultural, 2011.

BARBOSA, Rita de Cássia. O cotidiano e as máscaras: a crônica de Carlos Drummond de Andrade. 1984. 3. v. Tese. (Doutorado em Literatura Brasileira) - Faculdade de Filosofia, Letras e Ciências Humanas, Universidade de São Paulo, 1984. 
CUNHA, Sylvio da. Os pássaros do retratista. Letras e Artes. Rio de Janeiro, n. 37, p. 10, 6 abr. $1947 \mathrm{a}$.

CUNHA, Sylvio da. Iluminura, gravura e fotografia. Letras e Artes. Rio de Janeiro, n. 44, p. 6, 8 jun. 1947b.

CUNHA, Sylvio da. Quando a fotografia se torna uma arte. Letras e Artes. Rio de Janeiro, n. 47, p. 6,6 jul. $1947 \mathrm{c}$.

CUNHA, Sylvio da. Antologia. Letras e Artes. Rio de Janeiro, n. 48, p. 6, 20 jul. 1947d.

CUNHA, Sylvio da. A fotografia pura. Letras e Artes. Rio de Janeiro, n. 51, p. 6, 17 ago. 1947e.

CUNHA, Sylvio da. Plástica e fotografia. Letras e Artes. Rio de Janeiro, n. 52, p. 6, 24 ago. 1947 f.

CUNHA, Sylvio da. Caprichos do olhar. Letras e Artes. Rio de Janeiro, n. 58, p. 8, 14 set. 1947g.

CUNHA, Sylvio da. A arte do retrato. Letras e Artes. Rio de Janeiro, n. 59, p. 8, 21 set. 1947 h.

CUNHA, Sylvio da. Fotografias da memória. Letras e Artes. Rio de Janeiro, n. 86, p. 11, 23 maio 1948.

DIDI-HUBERMAN, Georges. A Pintura Encarnada. Seguido de A Obra-prima Desconhecida. Tradução de Osvaldo Fontes Filho e Leila de Aguiar Costa. São Paulo: Escuta, 2012.

DIDI-HUBERMAN, Georges. A semelhança informe: ou o gaio saber visual segundo Georges Bataille. Tradução de Caio Meira, Fernando Scheibe. Rio de Janeiro: Contraponto, 2015.

FONTES FILHO, Osvaldo. Prefácio à edição brasileira. In: DIDI-HUBERMAN, Georges. A Pintura Encarnada. Seguido de A Obra-prima Desconhecida. Tradução Osvaldo Fontes Filho e Leila de Aguiar Costa. São Paulo: Escuta, 2012. p. 9-17.

GLEDSON, John. Influências e impasses. São Paulo: Companhia das Letras, 2003.

HOLANDA, Sérgio Buarque de. O espírito e a letra: estudos de crítica literária II (1948- 1959). Organização, introdução e notas de Antonio Arnoni Prado. São Paulo: Companhia das Letras, 2010.

MERQUIOR, José Guilherme. Verso Universo em Drummond. Tradução de Marly de Oliveira. 3. ed. São Paulo: É Realizações, 2012.

MOLDER, Maria Filomena. Símbolo, Analogia e Afinidade. Lisboa: Edições Vendaval, 2009.

PY, Fernando. Bibliografia comentada de Carlos Drummond de Andrade: 1918-1934. 2. ed., ver. e aum. Rio de Janeiro: Edições Casa de Rui Barbosa, 2002.

RANCIÈRE, Jacques. O destino das imagens. Tradução de Mônica Costa Netto e organização de Tadeu Capistrano. Rio de Janeiro: Contraponto, 2012.

SANTIAGO, Silviano. Posfácio. In: ANDRADE, Carlos Drummond de. Farewell. Rio de Janeiro: Record, 1996, p. 105-129.

VALÉRY, Paul. Maus pensamentos \& Outros. Tradução de Pedro Sette-Câmara. Belo Horizonte;Veneza: Editora Âyiné, 2016. 
